\title{
Assessment of the level of vaccine-induced anti-HBs antibodies in children with inflammatory systemic connective tissue diseases treated with immunosuppression
}

\author{
Izabela Szczygielska, Elżbieta Hernik, Małgorzata Kwiatkowska, Lidia Rutkowska-Sak, \\ Beata Kołodziejczyk, Agnieszka Gazda \\ Department and Polyclinic of Rheumatology of Developmental Age, Institute of Rheumatology in Warsaw, Poland
}

\begin{abstract}
Objectives: Protective vaccinations are the most effective method of prevention of type B virus hepatitis. The aim of the study was to determine whether in children receiving immunosuppressive therapy due to inflammatory systemic connective tissue diseases the protective concentration of the anti-HBs antibodies produced after vaccination against type $B$ virus hepatitis in infancy is maintained.

Material and methods: The concentration of anti-HBs antibodies was assessed in the sera of 50 children with inflammatory connective tissue diseases - 37 girls (74\%) and 13 boys (26\%), aged 1.5-17.5 years - during the immunosuppressive treatment, which lasted at least 6 months. The control group consisted of 50 healthy children -28 girls (56\%) and 22 boys (44\%) aged $2-17$ years. All children were vaccinated in infancy with Engerix B vaccine according to the $0-1-6$ months schedule. The antibody concentration of $\geq 10 \mathrm{mIU} / \mathrm{ml}$ in patients is regarded as protective.

Results: No protective antibody concentrations were found in 25 cases (50\%) in the group of diseased children and only in 2 children in the control group (4\%).

Conclusions: The concentration of vaccine-induced antibodies should be assessed in children with inflammatory systemic connective tissue diseases and, in case of the absence of a protective concentration, revaccination should be started. The use of glucocorticosteroids, synthetic and biological disease-modifying antirheumatic drugs is no contraindication to vaccination against hepatitis $B$.
\end{abstract}

Key words: vaccination against virus hepatitis, concentration of anti-HBs antibodies, seroprotection.

\section{Introduction}

In spite of continuous progress in knowledge, infection with hepatitis B virus (HBV) still remains one of the greatest epidemiological problems of our times.

It is estimated that one third of the world's population, i.e. about two billion people, are infected, and 350-400 million of them actually have chronic type B virus hepatitis [1].

About 500000 to 1 million patients die yearly due to complications such as hepatocellular carcinoma or liver cirrhosis [2].
The epidemiological situation of HBV infections improved significantly after introduction of protective vaccinations. Taiwan was the first country to introduce protective vaccinations, in 1984 . During 10 years the incidence rate in that country decreased from $10 \%$ to less than $1 \%[3,4]$. In Poland, vaccination against HBV was introduced to the vaccination schedule in 1989. Initially, the vaccinations were given only to neonates born to mothers with positive HBs antigen test results. In subsequent years the vaccination programme was gradually extended, to include healthcare personnel, people

Address for correspondence:

Izabela Szczygielska, Department and Polyclinic of Rheumatology of Developmental Age, Institute of Rheumatology in Warsaw,

Spartańska 1, 02-637 Warsaw, Poland, e-mail: iza.szczygielska@op.pl

Submitted: 16.12.2014; Accepted: 31.03.2015 
exposed to close contact with HBV-infected patients, and patients with chronic disease. In 1994 vaccination against hepatitis B was introduced to the obligatory vaccination schedule. Initially, the vaccination schedule involved neonates born in 13 provinces, and since 1996, in the whole country [5].

Already within two years following introduction of vaccination, the incidence of hepatitis $B$ in the group of children aged three years or less was reduced by half from 39.8 to 19.9 per 100,000 population. Currently, in the group of the youngest children only isolated cases of the disease are reported, and they concern children not vaccinated or vaccinated with the variance of the vaccination schedule [6].

In 2012 the official rate of acute hepatitis B incidence in the Polish population was 0.2/100,000 [7]. Currently, in spite of widespread protective vaccinations, the largest groups of infected persons are young adults aged 17-20 years, in the time of sexual initiation, and elderly non-vaccinated persons [7].

The vaccination efficacy is regarded as high; it is estimated to induce immunity in over $95 \%$ of healthy vaccinated subjects [3].

The immunity after the vaccination is dual: humoral, associated with the presence of specific neutralizing antibodies (anti-HBs); and cellular, associated with $\mathrm{T}$ and $B$ cells. Owing to $T$ and $B$ memory cells the immunity to HBV infection is maintained in healthy persons, in whom no protective concentration of anti-HBs antibodies (anti-HBsAb) is detected.

Until recently, the protective serum concentration of anti-HBsAb was defined as a concentration not lower than $10 \mathrm{mIU} / \mathrm{ml}$, determined at least four weeks after the administration of the third vaccine dose. Currently, according to the latest instructions of the Polish Protective Vaccinations Schedule for 2014, in correctly vaccinated healthy subjects, the presence of antibodies (several years following the vaccination), in any concentration, proves the development of immunity, and no booster doses are recommended [8].

Revaccination after the primary vaccination, if the anti-HBsAb concentration is $<10 \mathrm{mlU} / \mathrm{ml}$, is recommended in the following subjects:

- chronically ill patients, particularly those with immunity disorders, frequently hospitalised, dialysed, infected with HIV, HCV, those with diabetes mellitus, renal and hepatic diseases, receiving immunosuppressive treatment, and also persons in close contact with a HBVinfected individual; the seroprotection index in such subjects should be $\geq 10 \mathrm{mIU} / \mathrm{ml}$,

- patients with malignant tumours on immunosuppressive treatment and patients after organ transplanta- tions. In such persons the seroprotection index should be $\geq 100 \mathrm{mlU} / \mathrm{ml}[8,9]$.

The revaccination, according to the recommendations, is started with one vaccine dose and in case of lack of response, the whole vaccination programme should be continued.

The subjects in whom after repeated revaccination no protective antibody concentration has been found should be treated as not responding to the vaccine, and in case of significant exposure to HBV, post-exposure management should be instituted [9].

It should also be kept in mind that the absence of anti-HBsAb after vaccination may be caused by HBV infection. In such cases HBV infection markers should be determined.

Children with inflammatory systemic connective tissue diseases (current name: autoimmune inflammatory rheumatic diseases - AIRDs) are at increased risk of infection, including HBV infection, compared with their healthy peers, in view of disturbed immune response, immunosuppressive treatment and, finally, frequent hospitalisations.

What conclusion could be drawn regarding the necessity of determination in AIRDs patients concentration of anti-HBsAb, irrespective of the type of rheumatic disease, its duration and the method of treatment, and, in case of lack of seroprotection, starting revaccination?

\section{Aim of the study}

The aim of the study was to determine whether in children receiving immunosuppressive therapy due to inflammatory systemic connective tissue diseases and vaccinated against hepatitis $B$ in infancy, the protective concentration of anti-HBsAb ( $\geq 10 \mathrm{mlU} / \mathrm{ml})$ is maintained.

\section{Material and methods}

The concentration of anti-HBs antibodies was determined in 50 children with inflammatory connective tissue diseases during immunosuppressive treatment, patients of the Department and Polyclinic of Rheumatology of Developmental Age, Institute of Rheumatology (IR).

Inclusion criteria:

- age: 2-18 years,

- documented vaccination against hepatitis B in infancy,

- documented diagnosis of rheumatic disease,

- minimum six months of immunosuppressive treatment,

- written consent of the parents for their child's participation in the study.

The control group consisted of 50 healthy children aged 2-18 years, with documented vaccination against hepatitis $B$ in infancy. 
Table I. Characteristics of the groups

\begin{tabular}{|lcc|}
\hline Girls & $\begin{array}{c}\text { Number of healthy } \\
\text { children (\%) }\end{array}$ & $\begin{array}{c}\text { Number of children } \\
\text { with AIRDs }(\%)\end{array}$ \\
\hline Boys & $37(74 \%)$ & $28(56 \%)$ \\
\hline Mean age & $13(26 \%)$ & $22(44 \%)$ \\
\hline $\begin{array}{l}\text { Time after the } \\
\text { last vaccination }\end{array}$ & $\begin{array}{l}1.5-17 \text { years }(2-17.7) \\
\text { (mean 10.8) }\end{array}$ & $\begin{array}{c}10.7 \text { years }(2-17.5) \\
\text { (mean 9.8) }\end{array}$ \\
\hline
\end{tabular}

Table II. Children with AIRDs - diagnosis

\begin{tabular}{|lcc|}
\hline Diagnosis & $\begin{array}{c}\text { Number } \\
\text { of } \\
\text { patients }\end{array}$ & $\%$ \\
\hline JIA systemic form & 6 & 12 \\
\hline JIA polyarticular form & 15 & 30 \\
\hline JIA oligoarticular form + uveitis & 4 & 8 \\
\hline JIA oligoarticular form & 3 & 6 \\
\hline Scleroderma & 10 & 20 \\
\hline $\begin{array}{l}\text { Mixed connective tissue disease } \\
\text { (MCTD) }\end{array}$ & 5 & 10 \\
\hline $\begin{array}{l}\text { Systemic lupus erythematosus } \\
\text { (SLE) }\end{array}$ & 2 & 4 \\
\hline Spondyloarthropathy & 2 & 4 \\
\hline Dermatomyositis (DM) & 1 & 2 \\
\hline Microscopic polyangiitis & 1 & 2 \\
\hline Scleromyositis & 1 & 2 \\
\hline
\end{tabular}

Table III. Children with AIRDs - treatment: 6 months to 12 years, average 4.2

GCS (orally and/or intravenously $0.5-2 \mathrm{mg} / \mathrm{kg}$ body weight, or in pulses $10-15 \mathrm{mg} / \mathrm{kg}$ body weight) combined therapy 46 children

Methotrexate $\geq 15 \mathrm{mg} / \mathrm{m}^{2}$ body surface area/week monotherapy or combined therapy - 41 children

Azathioprine $1-3 \mathrm{mg} / \mathrm{kg}$ body weight/day - combined therapy -8 children

Mycophenolate mofetil $-600 \mathrm{mg} / \mathrm{m}^{2}$ body surface area combined therapy -1 child

Cyclosporine A 3-5 $\mathrm{mg} / \mathrm{kg}$ body weight/day - combined therapy -6 children

Immunoglobulin infusions $2 \mathrm{~g} / \mathrm{kg}$ body weight/day - combined therapy -3 children

Biological drugs - 10 children: combined therapy

7 children etanercept $0.8 \mathrm{mg} / \mathrm{kg}$, body weight/week

2 children adalimumab $40 \mathrm{mg} / 2$ weeks

1 child canakinumab $0.4 \mathrm{mg} / \mathrm{kg}$ body weight/4 weeks
All children were vaccinated according to the $0-1-6$ months schedule with the Engerix $B$ vaccine (Glaxo SmithKline). The concentration of anti-HBsAB was determined by the immunochemistry method using a Vitros ECIQ analyser, Ortho Clinical Diagnostics J\&J.

Statistical methods: the comparison of the groups and subgroups with respect to antibody concentration was done using the Mann-Whitney test. The comparison of the groups with respect to vaccination efficacy was done using Fisher's exact test. The relationship between the time after the last vaccination and the concentration of antibodies for each group was assessed by calculating the Spearman rank correlation coefficient. All calculations were done using R 3.0.1 software. The study was conducted with consent of the Bioethical Committee at the IR.

The characteristics of the study groups are shown in Tables I, II and III.

\section{Results}

In the group of children with AIRDs, in 25 (50\%) cases no protective anti-HBsAb concentration was found, including concentration below $10 \mathrm{mlU} / \mathrm{ml}$ in 18 (36\%) children, and the absence of anti-HBsAb $(0 \mathrm{mlU} / \mathrm{ml})$ in 7 (14\%) children.

In the control group, seroprotection was found in 48 children (96\%): in 32 children (62\%) the concentration was $>10 \mathrm{mlU} / \mathrm{ml}$ and in 16 children (34\%) it was $<10 \mathrm{mlU} / \mathrm{ml}$. In 2 children (4\%) no anti-HBsAb concentration $(0 \mathrm{mlU} / \mathrm{ml})$ was detected. The differences were statistically significant $(p<0.0001)$.

The arithmetic mean of anti-HBsAb concentration was comparable in the two groups; it was $102.1( \pm 221.3)$ in the group of children with AIRDs and $114.8( \pm 244.9)$ in the healthy controls. No statistically significant differences were found ( $p=0.396)$.

No statistically significant correlation was found between the time after the last vaccination and the concentration of antibodies in both groups. In the group of children with AIRDs the correlation coefficient was 0.03 $(p=0.81)$, while that in the healthy controls was 0.16 $(p=0.27)$.

Additionally, no statistically significant correlation was found between duration of the treatment and the concentration of antibodies ( $r$ ho $=0.06, p=0.66$ ).

\section{Discussion}

Our study, despite the small number of study patients, calls attention to the potential weight of the problem. In $50 \%$ of the children with AIRDs participating in the study no seroprotection against hepatitis B was found (anti-HBsAb concentration < $10 \mathrm{mlU} / \mathrm{ml}$ ). 
For chronically ill patients receiving immunosuppressive treatment, such a concentration is not protective. In the control group, almost all healthy children (96\%) had antibody concentrations regarded as protective $(62 \%$ $>10 \mathrm{mlU} / \mathrm{ml}$ and $34 \%<10 \mathrm{mlU} / \mathrm{ml}$ ).

According to the current standards, a correctly vaccinated healthy person is immune, even after a long time following the vaccination, irrespective of anti-HBsAb concentration.

The results of most studies confirm the safety and immunogenicity of vaccines, inactivated or recombined, including those against hepatitis B.

As literature data show, in adult patients with systemic lupus erythematosus (SLE) according to Kuruma et al., Behçet's disease according to Erkek et al. and in patients with rheumatoid arthritis according to Elkayam, vaccination against hepatitis B has been proved safe and effective [10-12]. A group of European League Against Rheumatism (EULAR) experts developed the guidelines for vaccinations of adult patients with AIRDs. According to these directives, vaccination against hepatitis $B$ is recommended in cases of increased risk of infection with the virus, e.g. when travelling to endemic regions, in healthcare professionals, or in those having close contact with a HBV-infected person. The vaccination is recommended only in patients in whom no protective concentration of anti-HBsAb has been found [13].

Similarly to the guidelines on vaccinations in adults, EULAR developed recommendations for vaccinations in children with rheumatic diseases. The recommendations suggest that inactivated vaccines can be used in children with rheumatic diseases treated with glucocorticosteroids (GCS) and synthetic and biological disease-modifying antirheumatic drugs, in concordance with the indications of the national vaccination schedule [14]. Dell' Era et al. recommend administration of inactivated vaccines to children with rheumatic diseases during the period of disease stability. They particularly recommend vaccinations against pneumococci and influenza. The vaccinations should be withdrawn only in cases of active disease or when the vaccination caused a recurrence of the disease [15].

According to Toplak et al. as well as Aikawa et al., vaccination against influenza is safe in patients with juvenile idiopathic arthritis (JIA) [16, 17].

Kasapçopur et al. demonstrated in their study the safety and efficacy of vaccination against hepatitis B. In a group of 39 children with JIA treated with methotrexate (MTX) and/or prednisone, vaccination against hepatitis B induced seroprotection in all cases. No adverse effects or disease exacerbation were observed after the vaccination. The concentration of specific antibodies was comparable to that in the control group of healthy children [18].

All our patients in whom no seroprotection was found were administered the recommended single dose of the vaccine. To date, the concentration of anti-HBsAb has been determined in 13 patients from that group. In these cases protective antibody concentration $\geq 10 \mathrm{mIU} /$ $\mathrm{ml}$ was found. No adverse effects or disease exacerbation were observed in any child after the vaccination. Further studies on a larger group of children could show whether the administration of a single recommended dose is sufficient.

The question arises, however, how frequently the concentration of anti-HBSAB should be monitored in AIRDs patients. While the guidelines concerning dialysed patients and those with malignancies are available, there are no recommendations as to children with rheumatic diseases.

According to the Polish Expert Group of the Team for Vaccinations, the concentrations of antibodies should be determined once a year in dialysed patients, and every six months in those with malignancies during immunosuppressive treatment [19].

Taking into account also the financial aspect (anti-HBsAb concentration determinations are not financed by the National Health Fund), it seems justified to determine anti-HBsAb concentration in children with rheumatic diseases before planned surgical operations and before the beginning of immunosuppressive treatment, and, possibly, to monitor the concentration of the antibodies during the treatment, for example, every 2-3 years.

\section{Conclusions}

1. The determination of anti-HBsAb concentration in children with rheumatic diseases is highly justified.

2. In case of a lack of seroprotection, revaccination should be started.

The authors declare no conflict of interest.

\section{References}

1. Pokorska-Lis M, Marczyńska M. Czy nastolatki szczepione W wieku niemowlęcym mają odporność przeciwko WZW B? Przegl Lek 2010; 67: 13-17.

2. Pawłowska M, Halota W. Charakterystyka zakażeń HBV i HCV wśród dzieci. Hepatologia 2006; 6: 17-20.

3. Pawłowska M. Wciąż musimy walczyć z wirusowym zapaleniem wątroby typu B. Hepatologia 2006; 6: 12-14.

4. Szczygielska I. Epidemiologia WZW B. Rozprawa doktorska. Warszawa 2006; 12-15.

5. Magdzik W. Wirusowe zapalenie wątroby typu B w Polsce do 2002 roku. Zasady zapobiegania i zwalczania w szczególności drogą uodporniania czynnego. PZH, Warszawa 2002; 49-54. 
6. Woynarowski M. Polski dziecięcy program interferonowy leczenia przewlekłego zapalenia wątroby typu B. Koncepcja, realizacja i efekty. Rozprawa habilitacyjna. AM 2005; 45-47.

7. Stępień M, Piwowarow G. Hepatitis B in Poland in 2012. Przegl Epidemiol 2014; 68: 257-263.

8. Program Szczepień Ochronnych na rok 2014. www.mp.pl/ szczepienia/aktualności.

9. Szenbron L, Kuchar E, Styczyńska-Kazubska J. Szczepienia przeciwko WZW typu B. Medycyna Praktyczna 2013; 1: 81-84.

10. Kuruma KA, Borba EF, Lopes MH, et al. Safety and efficacy of hepatitis $B$ vaccine in systemic lupus erythematosus. Lupus 2007; 16: 350-354.

11. Erkek E, Ayaslioglu E, Erkek AB, et al. Response to vaccination against hepatitis $B$ in patients with Behçet's disease. J Gastroentreol Hepatol 2005; 20: 1508-1511.

12. Elkayam O, Yaron M, Caspi D. Safety and efficacy of vaccination against hepatitis $B$ in patients with rheumatoid arthritis. Ann Rheum Dis 2002; 61: 623-625.

13. van Assen S, Agmon-Levin N, Elkayam O, et al. EULAR recommendations for vaccination in adult patients with autoimmune inflammatory rheumatic diseases. Ann Rheum Dis 2011; 70: 414-422.

14. Żuber Z, Rutkowska-Sak L, Sobczyk M, et al. Szczepienia a leczenie biologiczne chorób reumatycznych. Reumatologia 2012; 50: 378-382.

15. Dell' Era L, Esposito S, Corona F, Principi N. Vaccination of children and adolescents with rheumatic diseases. J Rheumatology 2011; 50: 1358-1365.

16. Toplak N, Subelj V, Kveder T, et al. Safety and efficacy of infuenza vaccination in a prospective longitudinal study of 31 children with juvenile idiopathic arthritis. Clin Exp Rheumatol 2012; 30: 436-444.

17. Aikawa N, Goldenstein-Schainberg C, Venderamini M. PReS-FINAL-2177: Safety and lack of autoantibody production following influenza H1N1 vaccination in patients with juvenile idiopathic arthritis. From 20th Pediatric Rheumatology European Society (PreS) Congres. Ljubljana, Slovenia, 25-29 September 2013.

18. Kasapçopur O, Cullu F, Kamburoğlu-Goksel A, et al. Hepatitis $B$ in children with juvenile idiopathic arthritis. Ann Rheum Dis 2004; 63: 1128-1130.

19. Matkowska-Kocjan A. Szczepienia przeciwko WZW typu B u chorej dializowanej. Medycyna Praktyczna 2012; 3: 77-79. 